Research Article

\title{
Effect of glimepiride compared with glibenclamide on post prandial blood sugar in type II diabetes mellitus patients
}

\author{
Meenu Rani ${ }^{1}$, Shailesh $\operatorname{Yadav}^{1}$, Seema Choudhary ${ }^{2}$, Seema Sharma $^{2}$, Surya Mani Pandey ${ }^{3}$
}

${ }^{1}$ Department of Pharmacology, MMIMSR, Mullana-133203,

Ambala, Haryana, India,

${ }^{2}$ Department of Community

Medicine, MAMC, Agroha-125047,

Hisar, Haryana, India,

${ }^{3}$ Assistant Prof. (M.Sc., MCA), MAMC, Agroha-125047, Hisar,

Haryana, India

Received: 19 November 2013

Accepted: 9 December 2013

\section{*Correspondence to:}

Meenu Rani,

Email: meenusaharan23@gmail.com

(C) 2014 Rani M et al. This is an open-access article distributed under the terms of the Creative Commons Attribution Non-Commercial License, which permits unrestricted non-commercial use, distribution, and reproduction in any medium, provided the original work is properly cited.

\begin{abstract}
Background: Diabetes mellitus is a major public health problem with many complications. The Global Burden of Diabetes Study has projected that there will be a $122 \%$ increase in the number of people with diabetes mellitus worldwide in 2025 compared to 1995 . Despite the availability of new agents for the treatment of type 2 diabetes mellitus oral sulfonylureas remain a cornerstone of therapy. Glibenclamide and glimepiride are widely used sulfonylurea antidiabetic drugs.

Methods: A randomized, open, parallel group study was conducted by the Department of Pharmacology in association with Department of Medicine at Maharishi Markandeshwar Institute of Medical Sciences \& Research (MMIMSR), Mullana, Ambala. Total 50 patients were divided into two groups I \& II. In Group I ( $\mathrm{n}=25)$ glibenclamide $(5-15 \mathrm{mg} /$ day) \& in Group II $(n=25)$ glimepiride (1-6mg/day) was administered for a period of 24 weeks and data analyzed by Student's " $t$ "- test.

Results: There was a significant improvement in the post prandial blood sugar score $(\mathrm{p}<0.05)$ in both the study groups (I\&II) after 24 weeks but post prandial blood level did not differ significantly $(p>0.05)$ between the two groups.

Conclusions: Both the drugs glibenclamide and glimepiride were effectively reduced post prandial blood sugar in both the groups. But these sulfonylurea drugs lowered post prandial blood sugar to a similar degree without significant difference between the two groups.
\end{abstract}

Keywords: Type II diabetes mellitus, Glimepiride, Glibenclamide, Post prandial blood sugar, Sulfonylureas

\section{INTRODUCTION}

Diabetes mellitus is a chronic progressive metabolic disorder characterized by hyperglycemia mainly due to absolute or relative deficiency of insulin hormone. ${ }^{1}$ According to the World Health Organization (WHO) report, India today heads the world with over 32 million diabetic patients and this number is projected to increase to 79.4 million by the year $2030 .^{2}$ This multi-factorial disease is hypothesized to damage cell membranes resulting in elevated oxidative stress. The major concern with diabetes clearly relates to marked increase of neuropathy and series morbidity and mortality related to the development of other complications. ${ }^{3}$ New recommendations for the classification and diagnosis of diabetes mellitus include the preferred use of the terms "type 1" and "type 2" instead of "IDDM" and "NIDDM" to designate the two major types of diabetes mellitus. ${ }^{4}$ Type 1 diabetes is results from a cellular-mediated autoimmune destruction of the beta -cells of the pancreas. Autoimmune destruction of beta-cells has multiple genetic predispositions and is also related to environmental factors that are still poorly defined. ${ }^{5}$ Type 2 diabetes- There are probably many different causes of this form of diabetes. Insulin secretion is defective in these patients and insufficient to compensate for insulin resistance. The risk of developing this form of diabetes increases with age, obesity, and lack of physical activity. ${ }^{5}$ 
If and when diet therapy fails, oral hypoglycemic agents are the usual next step in the therapeutic armamentarium. ${ }^{6}$ Glibenclamide \& glimepiride both are second-generation sulfonylureas. ${ }^{7}$ The main effect of sulfonylurea (including glimepiride) is increase in the beta cells insulin release as a response to the serum glucose level. It is well established that sulfonylureas produce insulin secretion and improve tissue utilization of glucose at cellular level which was responsible for lowering of blood glucose level. ${ }^{8}$

\section{METHODS}

This randomized, open, parallel group study was conducted in the patients suffering from type 2 diabetes mellitus by the Department of Pharmacology in association with Department of Medicine at Maharishi Markandeshwar Institute of Medical Sciences \& Research (MMIMSR), Mullana, Ambala. All the patients visiting the Department of Medicine, MMIMSR, Mullana were screened and 65 patients of both the sexes suffering from type 2 diabetes mellitus were selected for the study. 15 patients were lost in the follow up period of the patients and were declared as drop outs from the study and thus 50 patients completed the study. All the patients gave their written consent before enrolment in the study. These patients were divided in group I \& II. Group I (25 patients): This group included the eligible patients diagnosed with type 2 diabetes mellitus and these patients were administered glibenclamide in dose range of 5-15 $\mathrm{mg} / \mathrm{day}$, for 24 weeks. Group II (25 patients): This group included the eligible patients diagnosed with type 2 diabetes mellitus and these patients were administered glimepiride in dose range of 1-6 mg/day, for 24 weeks. Patients with history of drug allergy, alcohol intake, congestive cardiac failure, female patients who were pregnant, lactating were excluded. Clinical evaluation of all the patients was done by measuring blood sugar before administration of drug. Efficacy of study drugs evaluated by measuring the post prandial blood level at start of pharmacotherapy, 2 weeks, 4 weeks and then every 4 weeks up to 24 weeks. Data were collected and the analysis of each variable was performed on the change from baseline values using Student's " $t$ "- test. A 'p' value less than or equal to 0.05 was considered statistically significant and $\mathrm{p}>0.05$-non significant.

\section{RESULTS}

The mean of all the baseline characteristics and SD in both groups were given (Table 1).

Table 1: Baseline characteristics in study groups.

\begin{tabular}{|lll|}
\hline Characteristic & Group I & Group II \\
\hline Number of patients & 25 & 25 \\
\hline Sex(Male/Female) & $12 / 13$ & $10 / 15$ \\
\hline Mean Age & $53.00 \pm 13.55$ & $54.08 \pm 11.69$ \\
\hline $\begin{array}{l}\text { Post prandial blood } \\
\text { sugar(mg/dl) }\end{array}$ & $264.45 \pm 64.39$ & $266.37 \pm 64.04$ \\
\hline
\end{tabular}

Data shows that the patients in group I started improving significantly with treatment as the mean scores of post prandial blood sugar reduced significantly $(\mathrm{p}<0.05)$ (Table 2).

Table 2: Mean scores of post prandial blood sugar in group I patients with treatment over 24 weeks.

\begin{tabular}{|lll|}
\hline & Mean \pm SD & p-value \\
\hline Baseline & $264.45 \pm 64.39$ & \\
\hline Week 2 & $262.13 \pm 63.84$ & $<0.05$ \\
\hline Week 4 & $260.29 \pm 63.93$ & $<0.05$ \\
\hline Week 8 & $258.29 \pm 64.29$ & $<0.05$ \\
\hline Week 12 & $256.81 \pm 64.25$ & $<0.05$ \\
\hline Week 16 & $255.81 \pm 64.49$ & $<0.05$ \\
\hline Week 18 & $251.93 \pm 64.59$ & $<0.05$ \\
\hline Week22 & $252.81 \pm 64.56$ & $<0.05$ \\
\hline Week 24 & $248.25 \pm 69.29$ & $<0.05$ \\
\hline
\end{tabular}

Data shows that the mean scores of post prandial blood sugar reduced significantly $(\mathrm{p}<0.05)$ (Table 3$)$.

Table 3: Mean scores of post prandial blood sugar in group II patients with treatment over 24 weeks.

\begin{tabular}{|lll|}
\hline & Mean \pm SD & p-value \\
\hline Baseline & $266.37 \pm 64.04$ & \\
\hline Week 2 & $262.93 \pm 64.09$ & $<0.05$ \\
\hline Week 4 & $260.57 \pm 64.15$ & $<0.05$ \\
\hline Week 8 & $257.73 \pm 64.08$ & $<0.05$ \\
\hline Week 12 & $255.25 \pm 64.26$ & $<0.05$ \\
\hline Week 16 & $253.09 \pm 64.68$ & $<0.05$ \\
\hline Week 18 & $252.13 \pm 64.73$ & $<0.05$ \\
\hline Week22 & $250.05 \pm 64.33$ & $<0.05$ \\
\hline Week 24 & $249.21 \pm 64.23$ & $<0.05$ \\
\hline
\end{tabular}

Data shows that change in post prandial sugar scores in both the groups did not differ significantly $(\mathrm{p}>0.05)$ (Table 4).

Table 4: Comparative mean scores of post prandial blood sugar in group I and group II patients over 24 weeks.

\begin{tabular}{|llll|}
\hline & $\begin{array}{l}\text { Group I } \\
\text { (Mean) }\end{array}$ & $\begin{array}{l}\text { Group II } \\
\text { (Mean) }\end{array}$ & p- value \\
\hline Baseline & $264.45 \pm 64.39$ & $266.37 \pm 64.04$ & 0.91 \\
\hline Week 2 & $262.13 \pm 63.84$ & $262.93 \pm 64.09$ & 0.96 \\
\hline Week 4 & $260.29 \pm 63.93$ & $260.57 \pm 64.15$ & 0.98 \\
\hline Week 8 & $258.29 \pm 64.29$ & $257.73 \pm 64.08$ & 0.97 \\
\hline Week 12 & $256.81 \pm 64.25$ & $255.25 \pm 64.26$ & 0.93 \\
\hline Week 16 & $255.81 \pm 64.49$ & $253.09 \pm 64.68$ & 0.88 \\
\hline Week 18 & $251.93 \pm 64.59$ & $252.13 \pm 64.73$ & 0.99 \\
\hline Week22 & $252.81 \pm 64.56$ & $250.05 \pm 64.33$ & 0.88 \\
\hline Week 24 & $248.25 \pm 69.29$ & $249.21 \pm 64.23$ & 0.96 \\
\hline
\end{tabular}

Between group comparison [unpaired student's ' $t$ ' test] 
Figure showing comparative change in post prandial blood sugar scores (Figure 1).

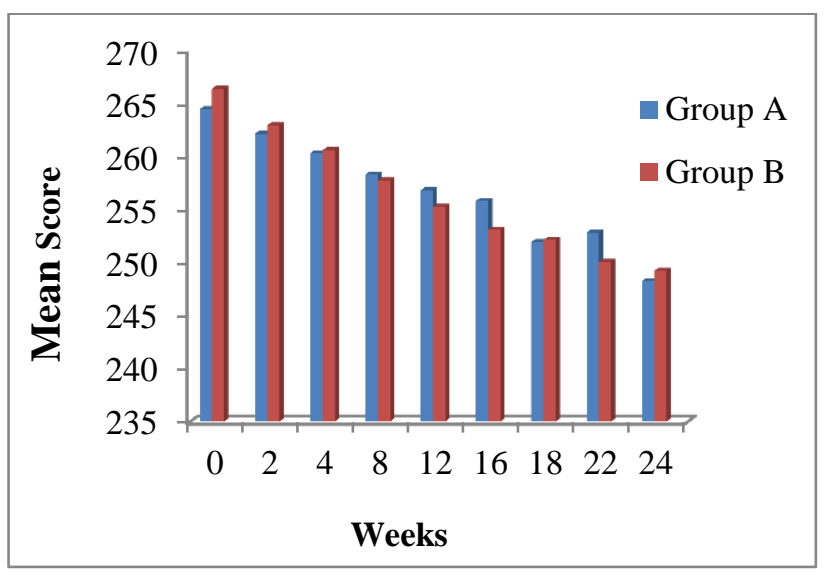

Figure 1: Comparative change in post prandial blood sugar scores.

\section{DISCUSSION}

DM virtually affects every system of the body mainly due to metabolic disturbances caused by hyperglycemia, especially if diabetes control over a period of time proves to be suboptimal. ${ }^{9}$ Until recently it was believed to be a disease occurring mainly in developed countries, but recent findings reveal a rise in number of new cases of type $2 \mathrm{DM}$ with an earlier onset and associated complications in developing countries ${ }^{10}$. Long-term complications of diabetes include retinopathy with potential loss of vision; nephropathy leading to renal failure; peripheral neuropathy with risk of foot ulcers, amputations, and Charcot joints; and autonomic neuropathy causing gastrointestinal, genitourinary, and cardiovascular symptoms and sexual dysfunction. Patients with diabetes have an increased incidence of atherosclerotic cardiovascular, peripheral arterial, and cerebrovascular disease. Hypertension and abnormalities of lipoprotein metabolism are often found in people with diabetes. ${ }^{11}$

The mean age of the patients in both the groups did not differ significantly $(\mathrm{p}>0.05)$. The mean age and SD in group A was $53.00 \pm 13.55$ and in Group B 54.08 \pm 11.69 (Table1).

The parameter used to assess the efficacy of drug therapy was the post prandial blood sugar during the study. The results showed that, in group $\mathrm{I}$, the mean score of post prandial blood sugar at baseline was $264.45 \pm 64.39$, at 4 weeks $260.29 \pm 63.93$ and at 24 weeks it dropped to $248.25 \pm 69.29$. In group II, the mean score of post prandial blood sugar at baseline was $266.37 \pm 64.04$, at 4 weeks $260.57 \pm 64.15$ and at 24 weeks, it dropped to $249.21 \pm 64.23$. Therefore patients in both the study groups started improving significantly with treatment by the end of $2^{\text {nd }}$ week as the mean scores of post prandial blood sugar reduced significantly $(\mathrm{p}<0.05)$.The improvement continued over time and mean scores were reduced significantly at the end of 24 weeks(Table 2and Table 3 ). Studies done by Groop et al. ${ }^{12}$ Skrapari I et al. ${ }^{13}$ and Abdul B et al. ${ }^{14}$ showed comparable results which were similar to the present study.

While comparing the mean scores of post prandial blood sugar in group I and group II patients over 24 weeks, change in post prandial blood sugar scores in both the groups also did not differ significantly $(p>0.05)$ and over the time both the groups maintained improvement which was comparable throughout the study. Studies done by Abdul B et al. ${ }^{14}$ showed comparable results which were similar to the present study.

\section{CONCLUSION}

During the study, it can be concluded that both glibenclamide and glimepiride are equally effective in reducing the post prandial blood sugar in type 2 diabetes mellitus patients but there is no difference in their efficacy as both the drugs lowered the post prandial blood sugar to similar extent.

\section{Funding: No funding sources Conflict of interest: None declared \\ Ethical approval: The study was approved by the Institutional Ethics Committee}

\section{REFERENCES}

1. Bihari Lal Shrivastava SR, Shrivastava PS, Ramasamy J. Role of self-care in management of diabetes mellitus. J Diabetes Metab Disord. 2013;12:14.

2. Muninarayana C, Balachandra G, Hiremath SG, Iyengar K, Anil NS. Prevalence and awareness regarding diabetes mellitus in rural Tamaka, Kolar. Int J Diabetes Dev Ctries. 2010Jan-Mar;30(1):18-21.

3. Saumya SM, Mahaboob B. Antioxidant effect of Lagerstroemia specicosapers (Banaba) leaf extract in streptozotocin-induced diabetic mice. Indian J Exp Biol. 2011;49 (2):125.

4. Mayfield J. Diagnosis and classification of diabetes mellitus: new criteria. Am Fam Physian. 1998 Oct;58(6):1355-62.

5. American Diabetes Association. Diagnosis and Classification of Diabetes Mellitus. Diabetes Care. 2012;35(1):64-71.

6. Miller LJ, Salman K, Shulman LH, Rose LI. Bed time insulin added to daytime sulfonylureas improves glycemic control in uncontrolled type 2 diabetes. Clin Pharmacol Ther. 1993Mar;53(3):3804.

7. Aquilante CL. Sulfonylurea pharmacogenomics in type 2 diabetes: the influence of drug target and diabetes risk polymorphisms. Expert Rev Cardiovasc Ther. 2010Mar;8(3):359-72.

8. Prashanth S, Kumar AA, Madhu B, Rama N, Sagar JV. Pharmacokinetic and pharmacodynamic drug 
interactions of carbamazepine and glibenclamide in healthy albino wistar rats. J Pharmacol Pharmacother. 2011Jan-Mar;2(1):7-10.

9. World health organization: Definition, diagnosis and classification of diabetes mellitus and its complications. Geneva: World health organization. 1999.

10. Chuang LM, Tsai ST, Huang BY, Tai TY: The status of diabetes control in Asia-a cross-sectional survey of 24317 patients with diabetes mellitus in 1998 . Diabet Med. 2002;19(12):978-85.

11. American Diabetes Association. Diagnosis and Classification of Diabetes Mellitus. Diabetes Care. 2009Jan;32:67.

12. Groop L, Wahlinboll E, Groop PH, Totterman KJ, Melander A, Tolppaner EM, et al. Pharmacokinetics and metabolic effects of glibenclamide and glipizide in type 2 diabetics. Eur $\mathrm{J}$ Clin Pharmacol. 1985;28(6):697-704.

13. Skrapari I, Perra D, Ioanndis I, Karabina SA, Elisaf M, Tselepis AD, et al. Glibenclamide improves postprandial hypertriglyceridaemia in type 2 diabetic patients by reducing chylomicrons but not the very low-density lipoprotein subfraction levels. Diabetic Medicine. 2001Oct;18(10):781-5.

14. Abdul B, Riaz M, Fawwad A. Glimepiride: evidence-based facts, trends, and observations. Vascular Health and Risk Management. 2012Aug;8:463-72.

doi:10.5455/2319-2003.ijbcp20140210

Cite this article as: Rani M, Yadav S, Choudhary S, Sharma S, Pandey SM. Effect of glimepiride compared with glibenclamide on post prandial blood sugar in type II diabetes mellitus patients. Int J Basic Clin Pharmacol 2014;3:96-9. 